International Journal of Biology, Pharmacy and Allied Seiences (IJBPAS) 'A Bridge Betuen Caboratory and Qnendo' Www.ijbpas.com

\title{
SMOKING AMONG SCHOOL STUDENTS - A SURVEY
}

\section{PRATHEEBHA $C^{1}$, DR.DHANRAJ GANAPATHY ${ }^{2 *}$, DR. KEERTHI SASANKA ${ }^{3}$}

1: Saveetha Dental College and Hospitals, Saveetha Institute of Medical and Technical Sciences, Saveetha University, 162, Poonamalle high road, Velapanchavadi, Chennai - 77.

2: Professor and Head, Department of Prosthodontics, Saveetha Dental College and Hospitals, Saveetha Institute of Medical and Technical Sciences, Saveetha University162,Poonamalle high road, Velapanchavadi, Chennai - 77.

3: Senior Lecturer, Department of Prosthodontics, Saveetha Dental College and Hospitals, Saveetha Institute of Medical and Technical Sciences, Saveetha University, 162, Poonamalle high road, Velapanchavadi, Chennai - 77

*Corresponding Author: E Mail: Dr. Dhanraj Ganapathy: dhanarajmganapathy@yahoo.co.in

Received $19^{\text {th }}$ March 2021; Revised 20 ${ }^{\text {th }}$ April. 2021; Accepted $19^{\text {th }}$ May 2021; Available online $1^{\text {st }}$ Aug. 2021 https://doi.org/10.31032/IJBPAS/2021/10.8.1035

\section{ABSTRACT}

Background: Adolescent tobacco smoking is a major health concern in India. Schools may be able to influence adolescent behaviour regarding smoking. Moreover, the prevalence of cigarette smoking varies between schools, and some of this variability may be explained by school factors. The World Health Organization (WHO) reported that mortality due to smoking-related diseases was higher than the combination of all infectious diseases worldwide. To know the smoking habits among school students. Questions were prepared and administered to 120 participants through survey planet an online survey. The study population were school students of age group between 13 to 18 years. The study estimated that $27 \%$ of the total participants smoked their first cigarette in their age of 16 to 19 years and $34 \%$ of the total participants smoked their first cigarette in the age group 11 and 15 years old. $25 \%$ of the people who smoke have given their opinion that their friends who smoke have influenced them even $28 \%$ of the total study population including the non smokers have suggested that television and movie advertising also 
influenced the students to smoke. $54 \%$ of the total study population (school students) are smoking. $28 \%$ of the smokers have decided that they will stop smoking.

Keywords: influence; adolescents; movie advertising; world health organisation INTRODUCTION

A repository for the collection, analysis, validation and dissemination of all smoking and health-related data was established by the World Health Organization (Saha et al., 2007). Smoking prevalence in men and women averages $42 \%$ and $24 \%$, respectively, for developed countries, and $48 \%$ and $7 \%$, respectively, for less developed countries. In the United States, in comparison approximately 47 million people smoke cigarettes . Both active and passive smoking are implicated in this increase, and several studies of smoking behaviour and disease incidence in women suggest greater susceptibility of women to tobacco carcinogens (Henschke, Yip and Miettinen, 2006). Comparative toxicity studies have shown that the new experimental cigarettes that in comparison with standard cigarettes heat tobacco have a relatively low toxicity (Foy et al., 2004). By measuring the intimalmedial thickness of the carotid artery in a large longitudinal atherosclerosis risk study of 10,914 individuals quantitative risk estimates were obtained. Increases of $50 \%$, $25 \%$ and $20 \%$ were shown over nonsmokers in current, ex-and passive smokers, respectively, thus suggesting a role of all types of tobacco smoke exposure in the progression of atherosclerosis (Howard et al., 1998).

Two polymorphic variants that interact with smoking to modify lung cancer risk have been identified (Nakachi et al., 1993) (Okada et al., 1994). Cigarette smoking is a major preventable cause of morbidity and mortality worldwide. Some time before 18 years of age, most adult smokers start smoking regularly (Meijer et al., 1996). Mortality and morbidity due to smokingrelated diseases are important public health issues globally (Organization and Others, 2011). The World Health Organization (WHO) reported that mortality due to smoking-related diseases was higher than the combination of all infectious diseases worldwide (Lim et al., 2017).

Even the other authors like Kuang Hock Lim, Hui Li Lim, Chien Huey Teh, Chee Cheong Kee, et al, conducted a survey among school-going adolescents in selected secondary schools in Peninsular Malaysiafindings from the Malaysian Adolescent Health Risk Behaviour (MyaHRB) study. A 
study was carried out in 2013, which involved a total of 40 secondary schools. They were randomly selected using a twostage clustering sampling method. Subsequently, all upper secondary school students (aged 16 to 17 years) from each selected school were recruited into the study. Data was collected using a validated standardised questionnaire and the prevalence of smoking among them were nearly $14.6 \%$ and it was significantly higher for males than the females. Previously our team has a rich experience in working on various research projects across multiple disciplines. (Muthukrishnan and Warnakulasuriya, 2018), (Govindaraju, Neelakantan and Gutmann, 2017), (Chen et al., 2019), (Priyanka et al., 2017), (Sitharthan et al., 2019), (Priyadharsini et al., 2018), (Azeem and Sureshbabu, 2018), (Wu et al., 2019), (Abitha and Santhanam, 2019), (Manohar and Abilasha, 2019), (Venu, Dhana Raju and Subramani, 2019), (Wang et al., 2019), (Girija, Jayaseelan and Arumugam, 2018), (Sheriff, Ahmed Hilal Sheriff and Santhanam, 2018), (Dhinesh et al., 2017) Now the growing trend in this area motivated us to pursue this project. Smoking nowadays is most common among the school students this survey was done to know the smoking prevalence percentage. It was also a comparative study between urban and rural school students. Our study aimed to know the smoking habits among school students.

\section{MATERIALS AND METHOD}

Self-administered design was designed based on awareness on the effects of smoking, sampling was done by Stratified Random sampling. Ethical approval and informed consent from the participants were obtained from the institutional review board. The questionnaire was distributed through an online survey planet link the study population included [number of school students ] belonging to $13-18$ years of age group. The participants were explained about the purpose of study in detail .The questions were carefully studied and the corresponding answers were marked by the participants. Only completed surveys were taken for analysis and the incomplete surveys were eliminated. All the responses obtained were tabulated and reliability of the data was checked. The participants did the survey voluntarily and no incentives were given to them.

\section{RESULTS}




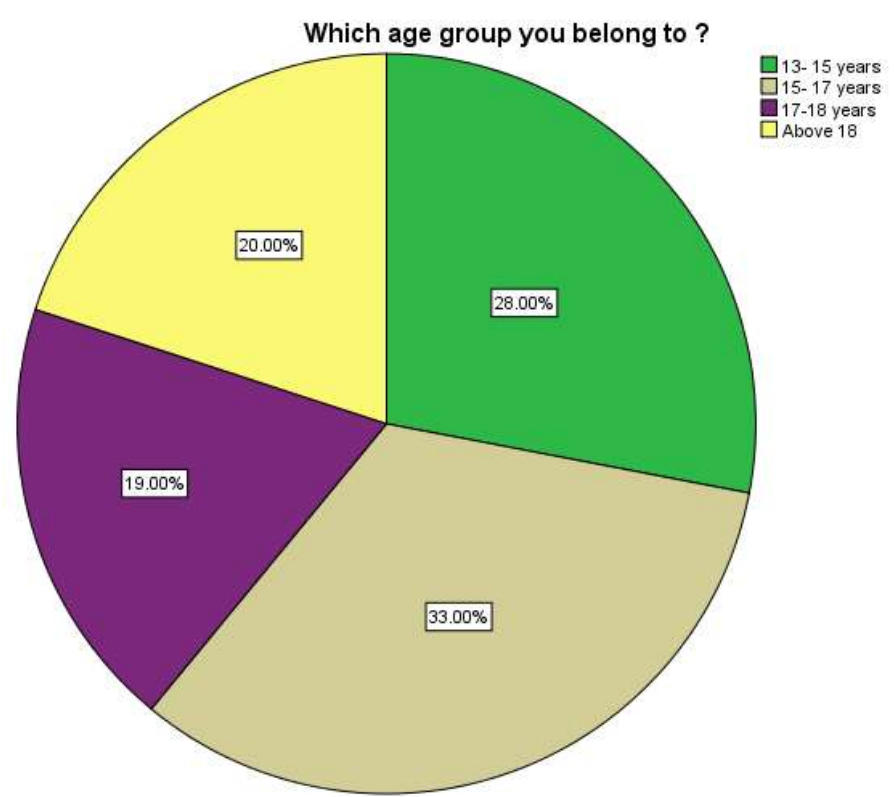

Figure 1: Pie chart represents the age group of the population of the survey. Many of the participants who were involved in the study were in the age group of $15-17$ years; $33 \%$ and $28 \%$ of the population belongs to the age group of 13-15 years. $19 \%$ of the respondents were from $17-18$ years, $20 \%$ of the respondents belonged to the age group of above 18 years.

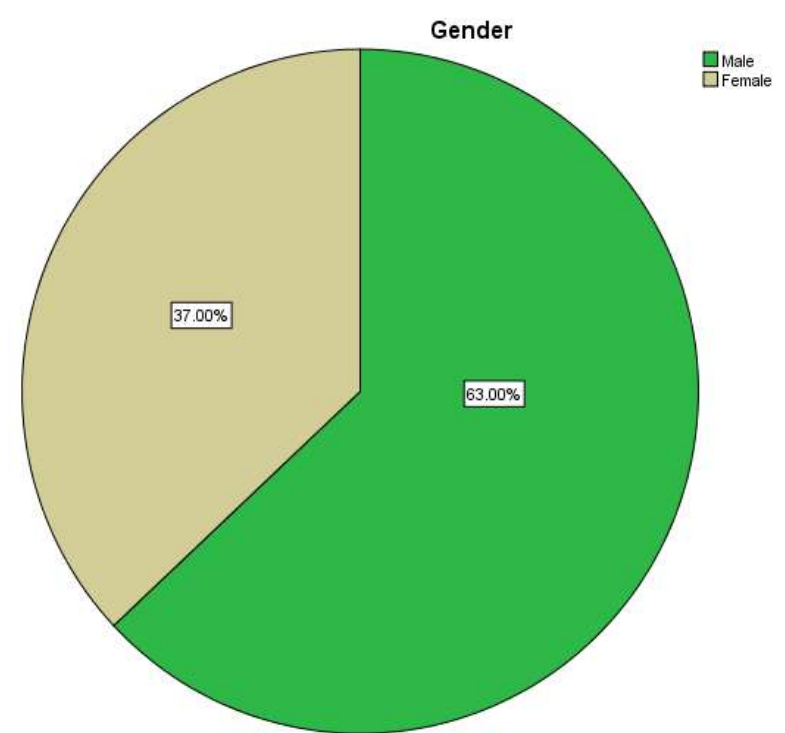

Figure 2: Pie chart represents the gender of the survey population. $63 \%$ of the respondents are male and $37 \%$ of the respondents are female 


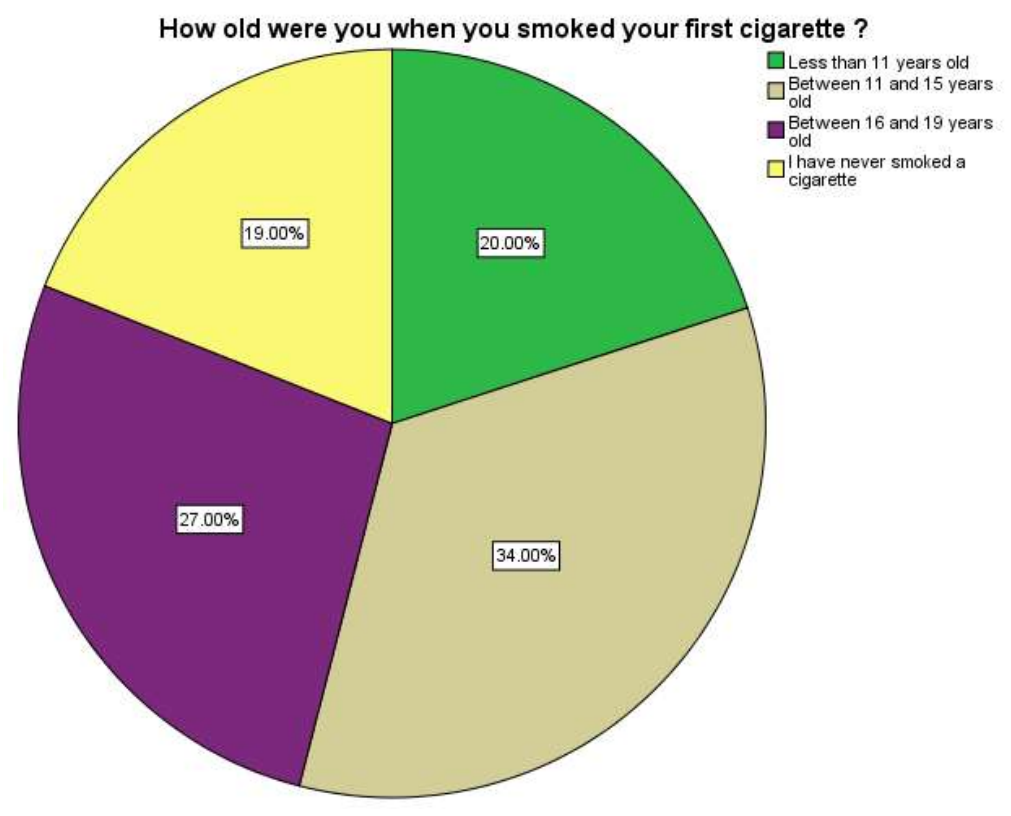

Figure 3: Pie charts represent the percentage of how old the respondents were when they smoked their first cigarette. $20 \%$ of the respondents were less than 11 years and $34 \%$ of the respondents were between 11 and 15 years and $27 \%$ of the respondents were between 16 and 19 years old

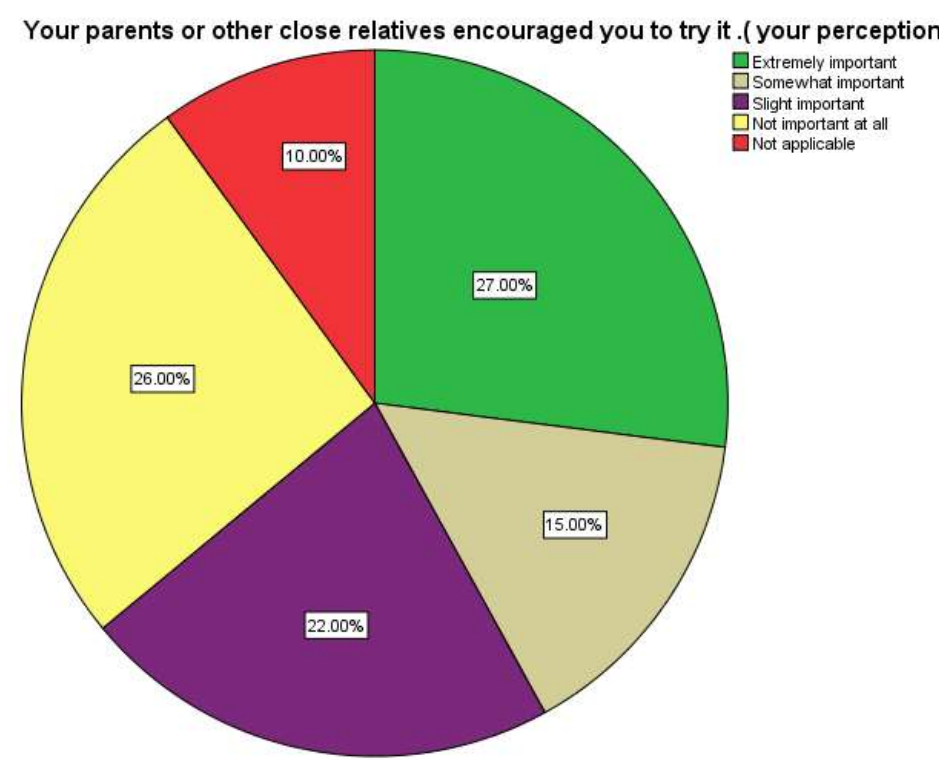

Figure 4: Pie chart represents the perception of respondents whether parents or other relatives would have been encouraged to smoke. $27 \%$ of respondents polled that the parents or the relatives would have encouraged them to smoke. $28 \%$ of respondents polled that the parents or the relatives would not have encouraged them to smoke 


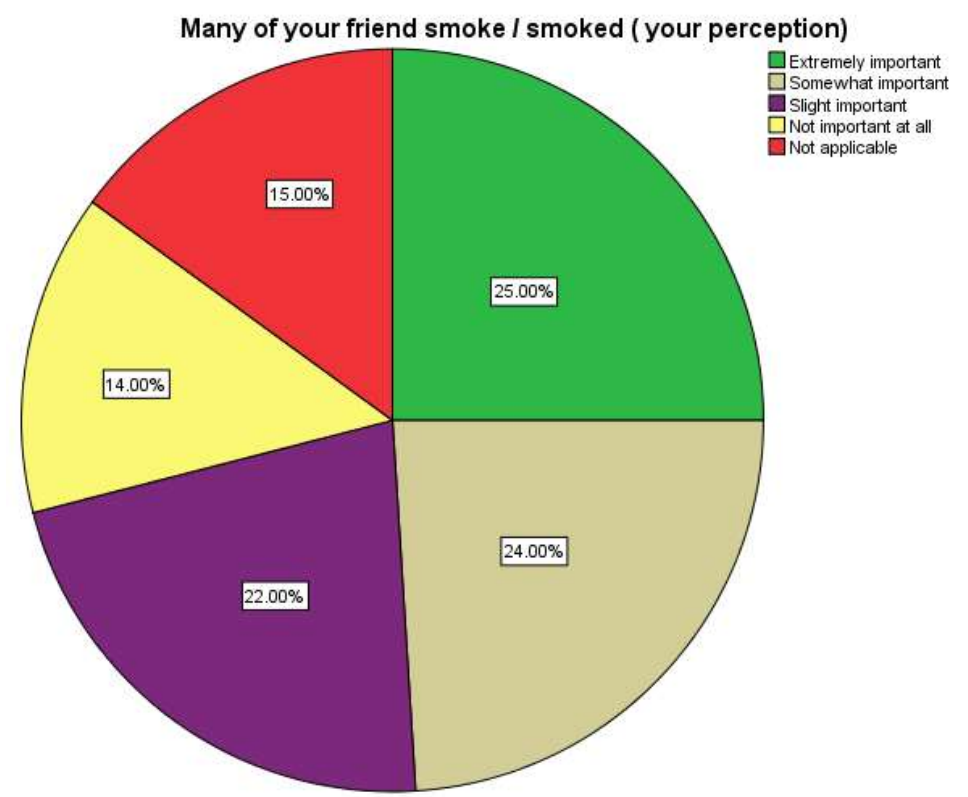

Figure 5: Pie chart represents the perception of respondents whether many of the friends smoke so because of that school children would have started this habit. $25 \%$ of respondents polled that many of their friends smoked so because of that they started smoking. $14 \%$ of respondents polled that this would not have encouraged them to smoke

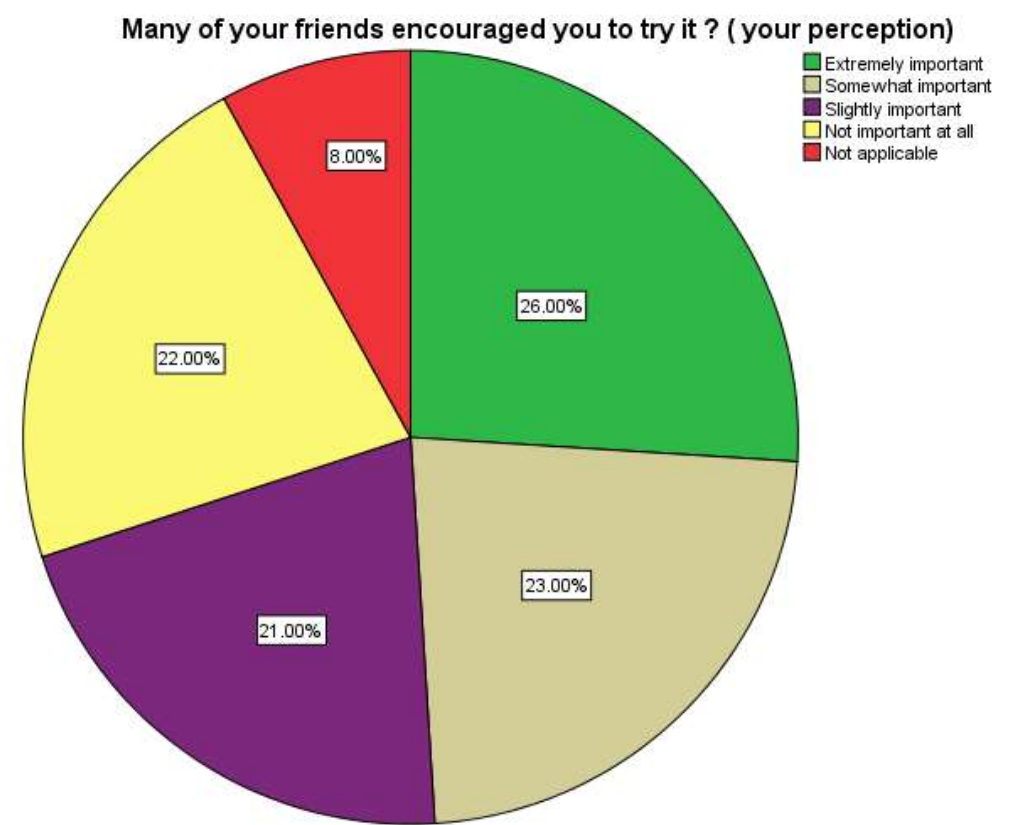

Figure 6: Pie chart represents the perception of respondents whether many of the friends would have encouraged them to smoke. $26 \%$ of the participants including non smokers have suggested that friends might have encouraged them to smoke and it's an extremely important factor. However, $22 \%$ of the participants' opinions were that friends would not be encouraged to smoke. 


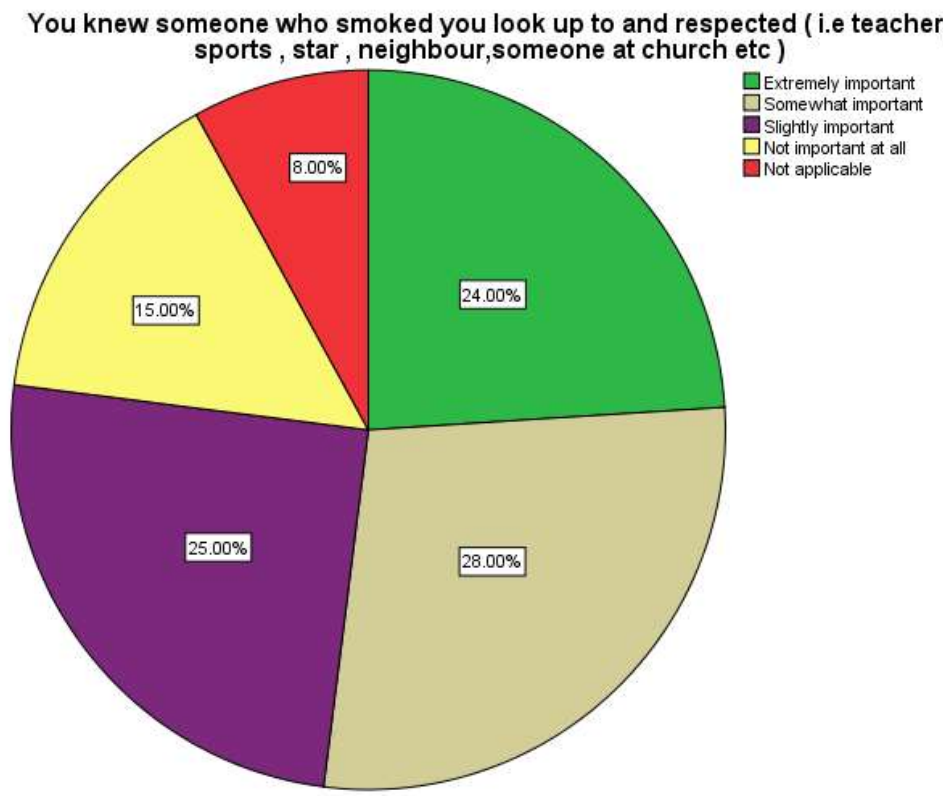

Figure 7: Pie chart represent the perception of respondents whether a person whom they look upto might have a smoking habit so this made them cultivate the same habit. $24 \%$ of the total population have suggested that students got influenced because of the person whom they look upto may smoke. It can be any film stars, celebrity, sports person, teacher, guide. $15 \%$ of the population have denied it.

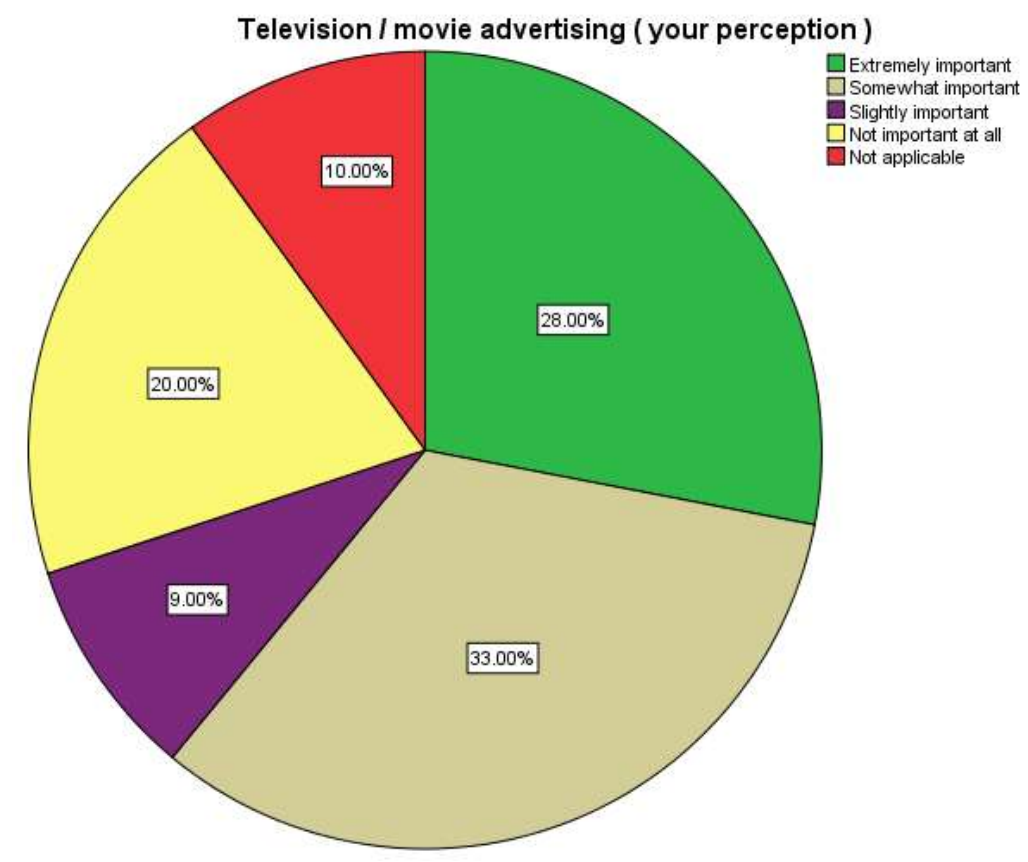

Figure 8: Pie chart represent the perception of respondents whether television or movies might have an impact on inculcating the smoking habit. $\mathbf{2 8 \%}$ of the survey participants including some of the non smokers have told that television and movie advertising will have a very good impact on the school students that will evoke them to smoke. $20 \%$ of people have denied it. 


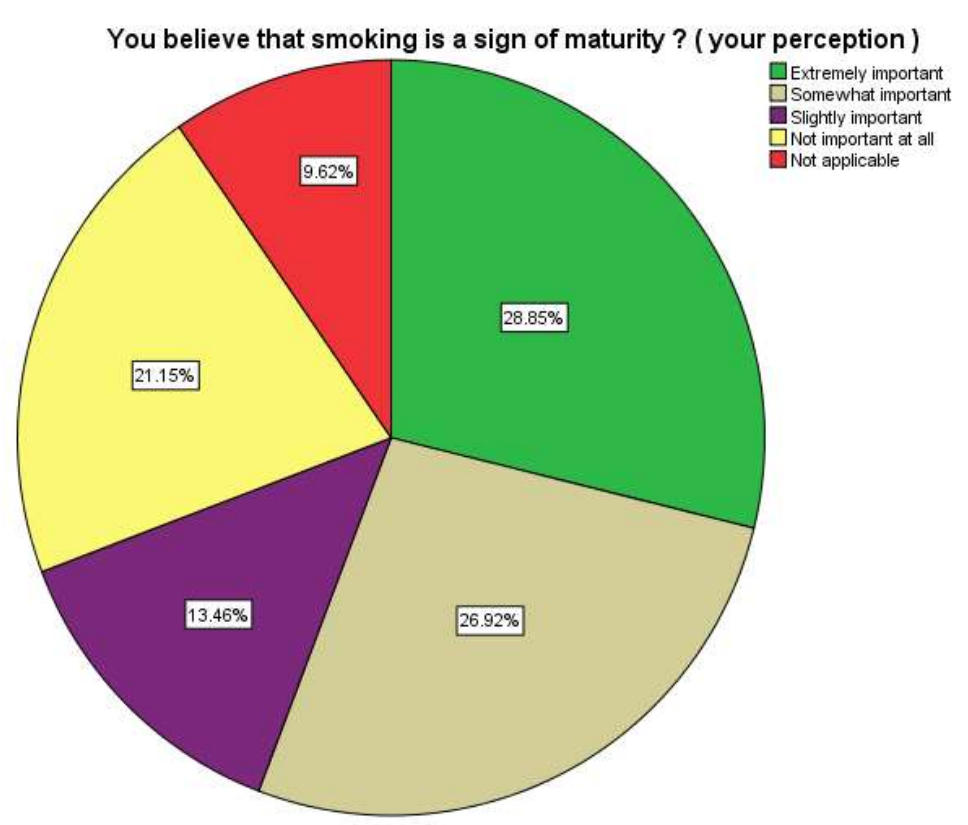

Figure 9: Pie chart represent the perception of respondents whether they believe that smoking is a sign of maturity. $\mathbf{2 8 . 3 5 \%}$ of the respondents thought that they might have started smoking thinking that it is a sign of maturity and $21.15 \%$ of the population have denied it

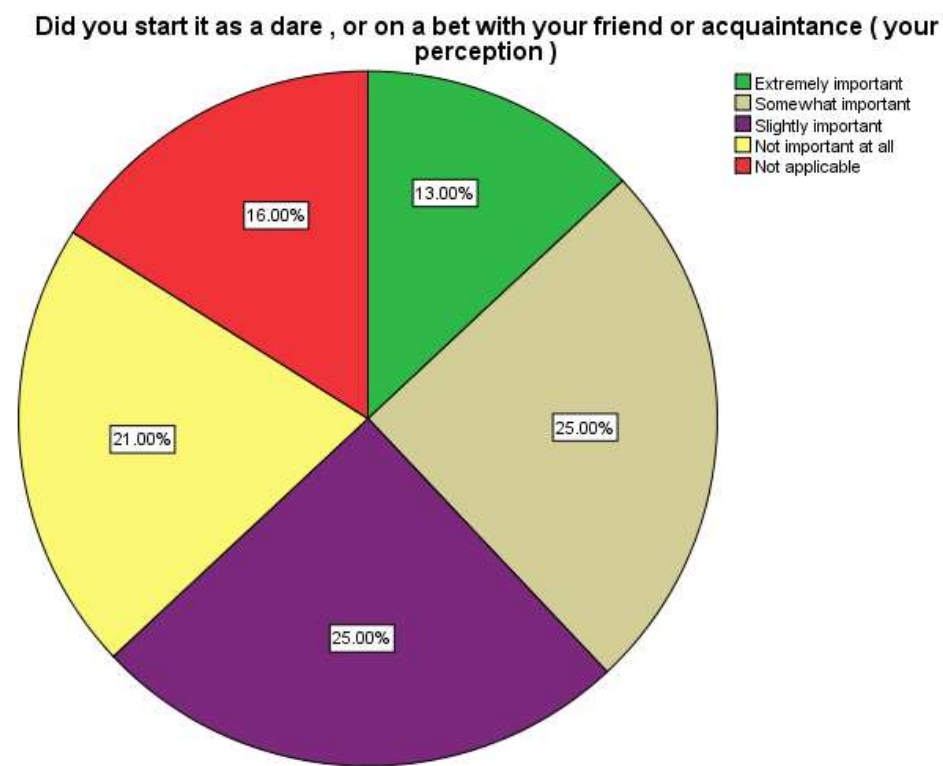

Figure 10: Pie chart represent the perception of respondents whether they started smoking as a bet or dare with your friend. $13 \%$ of the people have polled for that they might have started smoking as a bet or dare with their friend or acquaintance and $21 \%$ denied it 


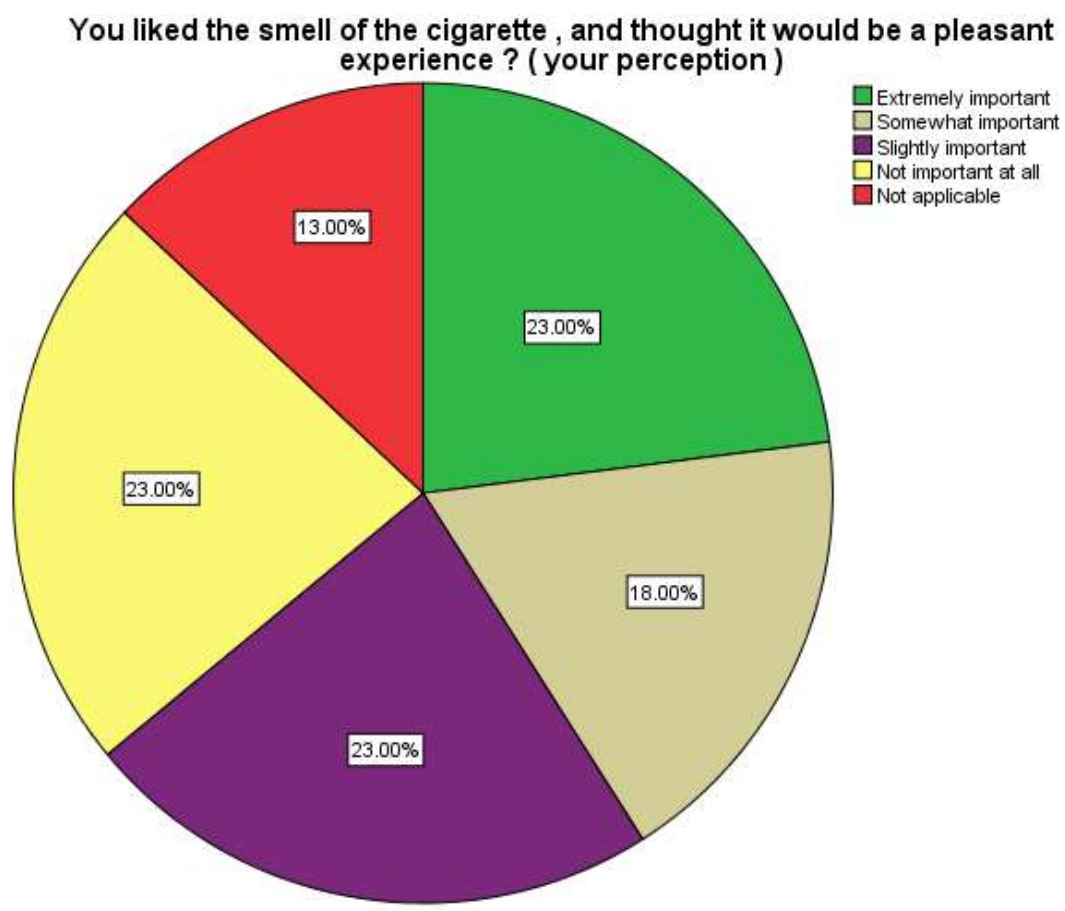

Figure 11: Pie chart represent the perception of respondents that since they liked the smell of the cigarettes, and thought it would be a pleasant experience. $23 \%$ of the smokers who have answered this question have accepted that they liked the smell of the cigarette so they continued smoking. $23 \%$ of them have denied it

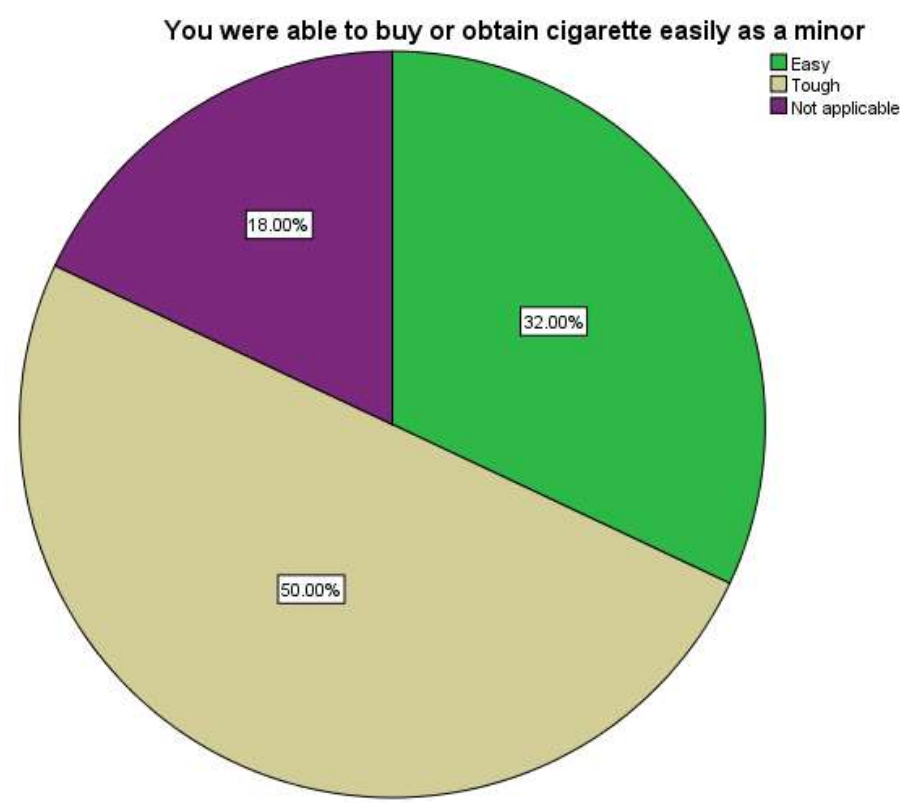

Figure 12: Pie chart represents the percentage of the respondents who were able to obtain cigarettes easily as a minor. $32 \%$ of the respondents said it was easy for them to obtain cigarettes. $50 \%$ of the respondents said it was tough for them to obtain cigarettes 


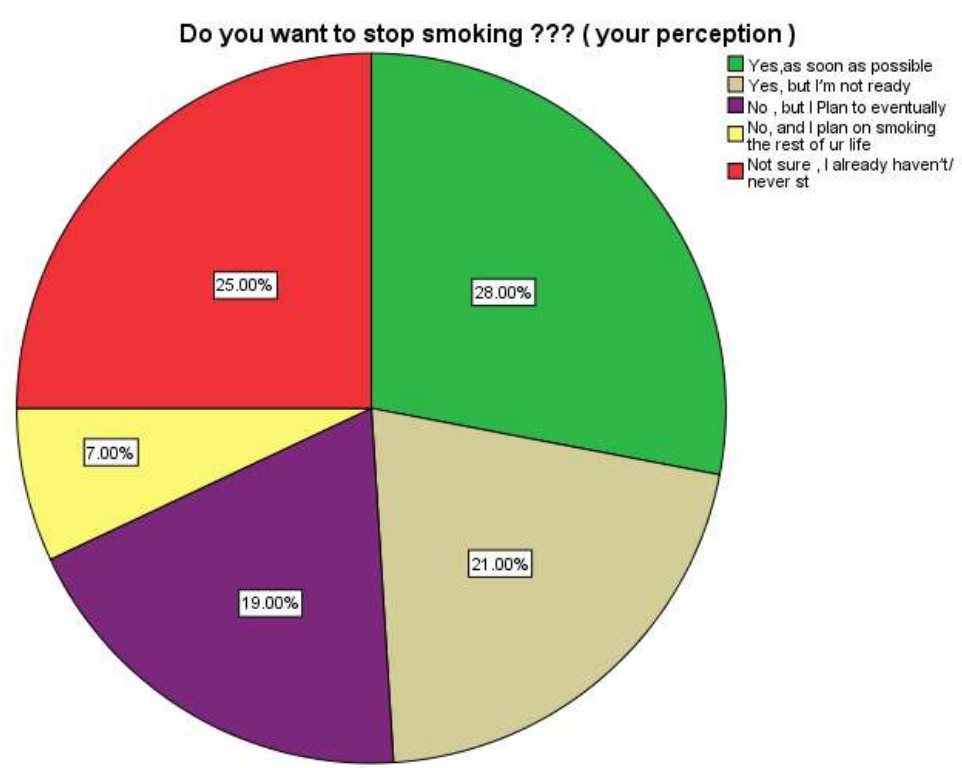

Figure 13: Pie chart represents the percentage of people who wanted to stop smoking. $28 \%$ of the people have said that as soon as possible they will stop smoking. $21 \%$ of the people are not ready to stop smoking. $7 \%$ of the people have decided to smoke the rest of their life. $26 \%$ of the people have already not started this smoking habit

\section{DISCUSSION}

Many of the participants who were involved in the study were in the age group of $15-17$ years that is $33 \%$ and $28 \%$ of the population belongs to the age group of 13-15 years and $19 \%$ of the respondents were from $17-18$ years. $20 \%$ of the respondents belonged to the age group of above 18 years (Figure 1). $63 \%$ of the respondents are male and $37 \%$ of the respondents are female (Figure 2). 20\% of the respondents were less than 11 years and $34 \%$ of the respondents were between 11 and 15 years and $27 \%$ of the respondents were between 16 and 19 years old when they smoked their first cigarette (Figure 3), A similar study was conducted by Yousif. M.Gadalla (Gadalla et al., 2012) in the year
2012 in which similar results were obtained by them - Age of initiation was as early as 11 years old, smoking between 11-13 years of age was 29 (23.4\%) and between 14-17 years $94(75.8 \%) .27 \%$ of respondents polled that the parents or the relatives would have encouraged them to smoke. $28 \%$ of respondents polled that the parents or the relatives would not have encouraged them to smoke (Figure 4). 25\% of respondents polled that many of their friends smoked so because of that they started smoking. $14 \%$ of respondents polled that this would not have encouraged them to smoke (Figure 5). 26\% of the participants including non smokers have suggested that friends might have encouraged them to smoke and it's an 
extremely important factor. However, $22 \%$ of the participants' opinions were that friends would not be encouraged to smoke (Figure 6). $24 \%$ of the total population have suggested that students got influenced because of the person whom they look upto may smoke. It can be any film stars, celebrity, sports person, teacher, guide.15\% of the population have denied it (Figure 7). $28 \%$ of the survey participants including some of the non smokers have told that television and movie advertising will have a very good impact on the school students that will evoke them to smoke. $20 \%$ of people have denied it (Figure 8). Much research has examined the influence of individual characteristics and characteristics in the immediate social environment (Conrad, Flay and Hill, 1992; Tyas and Pederson, 1998; National Center for Chronic Disease Prevention and Health Promotion (US) Office on Smoking and Health, 2012). $28.35 \%$ of the respondents thought that they might have started smoking thinking that it is a sign of maturity and $21.15 \%$ of the population have denied it (Figure 9). $13 \%$ of the people have polled for that they might have started smoking as a bet or dare with their friend or acquaintance and $21 \%$ denied it (Figure 10). 23\% of the smokers who have answered this question have accepted that they liked the smell of the cigarette so they continued smoking. $23 \%$ of them have denied it (Figure 11). $32 \%$ of the respondents said it was easy for them to obtain cigarettes. $50 \%$ of the respondents said it was tough for them to obtain cigarettes (Figure 12). 28\% of the people have said that as soon as possible they will stop smoking. $21 \%$ of the people are not ready to stop smoking. $7 \%$ of the people have decided to smoke the rest of their life. $26 \%$ of the people have already not started this smoking habit (Figure 13).

Preventing young people from starting to smoke is critical and a crucial step for cancer control. The Theory of Triadic Influence (Flay, Petraitis and Hu, 1999) posits that factors from three different levels of context can influence youth smoking onset:, characteristics in the immediate social environment surrounding youth (e.g., friends and family members), individual characteristics (e.g., age and gender), and characteristics in the broader social environment surrounding youth (e.g., school community). Students are at increased risk for smoking if they (a) often see students smoking near their school, (b) attend a school with a relatively high senior student smoking rate, and (c) report that students at their school smoke where they are not allowed 
(Leatherdale and Manske, 2005). Few studies have examined how school characteristics are related to youth smoking behavior. Considering that smoking rates vary across schools (Aveyard, Markham and Cheng, 2004) (Aveyard et al., 2005) and that the variation is not caused by differences in student characteristics, it is important to identify the influential school characteristics associated with that variability.

Different risks and protective factors related to smoking have been described among adolescents in the last decades (Hawkins, Catalano and Miller, 1992). These factors manifest themselves at different levels (e.g., personal, familial, school level) introducing complexity when trying to understand the behaviour of adolescents. Several authors have found significant intra-school correlations in smoking onset, monthly smoking prevalence and the number of cigarettes smoked per day, which could be related to the characteristics of the students within each school or other school contextual features. Those studies exploring contextual effects using multilevel modelling have found that schools with a combination of higher performance and less truancy (Aveyard et al., 2004), schools receiving social assistance (Linetzky et al., 2012) and mixed sex or vocational high schools had a higher risk for smoking (Heo et al., 2014). Our institution is passionate about high quality evidence based research and has excelled in various fields (Pc, Marimuthu and Devadoss, 2018; Ramesh et al., 2018; Vijayashree Priyadharsini, Smiline Girija and Paramasivam, 2018; Ezhilarasan, Apoorva and Ashok Vardhan, 2019; Ramadurai et al., 2019; Sridharan et al., 2019; Vijayashree Priyadharsini, 2019; Chandrasekar et al., 2020; Mathew et al., 2020; R et al., 2020; Samuel, 2021). We hope this study adds to this rich legacy.

\section{Limitation:}

This is an online survey were bias can be expected from respondents, sampling and selection error, less sample size

\section{Future Scope:}

In future this study can be conducted on different professionals and students which assess various behavioural and knowledge patterns and their psychological or physical stress, can be considered with the habit of smoking and its prevalence with different professions.

\section{CONCLUSION}

This study concludes that almost half of the total study population (school students) are smoking, among them the majority of the smokers have an idea to stop their smoking 
habit but few of them do not have any idea to stop the habit of smoking

\section{ACKNOWLEDGEMENT}

We thank Saveetha Dental College and Hospitals for providing us the support to conduct the study.

\section{CONFLICT OF INTEREST}

The author declares that there was no conflict of interest in the present study

\section{REFERENCES}

[1] Abitha, T. and Santhanam, A. (2019) 'Correlation between bizygomatic and maxillary central incisor width for gender identification', Brazilian Dental Science. Available at: https://bds.ict.unesp.br/index.php/cob /article/view/1775.

[2] Aveyard, P. et al. (2004) 'The influence of school culture on smoking among pupils', Social science \& medicine, 58(9), pp. 17671780 .

[3] Aveyard, P. et al. (2005) 'Is interschool variation in smoking uptake and cessation due to differences in pupil composition? A cohort study', Health \& place, 11(1), pp. 55-65.

[4] Aveyard, P., Markham, W. A. and Cheng, K. K. (2004) 'A methodological and substantive review of the evidence that schools cause pupils to smoke', Social science \& medicine, 58(11), pp. 2253-2265.

[5] Azeem, R. A. and Sureshbabu, N. M. (2018) 'Clinical performance of direct versus indirect composite restorations in posterior teeth: A systematic review', Journal of conservative dentistry: JCD, 21(1), pp. 2-9.

[6] Chandrasekar, R. et al. (2020) 'Development and validation of a formula for objective assessment of cervical vertebral bone age', Progress in orthodontics, 21(1), p. 38.

[7] Chen, F. et al. (2019) '6-shogaol, a active constiuents of ginger prevents UVB radiation mediated inflammation and oxidative stress through modulating $\mathrm{NrF} 2$ signaling in human epidermal keratinocytes (HaCaT cells)', Journal of photochemistry and photobiology. B, Biology, 197, p. 111518.

[8] Conrad, K. M., Flay, B. R. and Hill, D. (1992) 'Why children start smoking cigarettes: predictors of onset', British journal of addiction, 87(12), pp. 1711-1724.

[9] Dhinesh, B. et al. (2017) 'An experimental analysis on the 
influence of fuel borne additives on the single cylinder diesel engine powered by Cymbopogon flexuosus biofuel', Journal of the Energy Institute, 90(4), pp. 634-645.

[10] Ezhilarasan, D., Apoorva, V. S. and Ashok Vardhan, N. (2019) 'Syzygium cumini extract induced reactive oxygen species-mediated apoptosis in human oral squamous carcinoma cells', Journal of oral pathology \& medicine: official publication of the International Association of Oral Pathologists and the American Academy of Oral Pathology, 48(2), pp. 115-121.

[11] Flay, B. R., Petraitis, J. and Hu, F. B. (1999) 'Psychosocial risk and protective factors for adolescent tobacco use', Nicotine \& tobacco research: official journal of the Society for Research on Nicotine and Tobacco, 1 Suppl 1, pp. S5965.

[12] Foy, J. W. D. et al. (2004) 'A comparison of in vitro toxicities of cigarette smoke condensate from Eclipse cigarettes and four commercially available ultra low“tar" cigarettes', Food and chemical toxicology: an international journal published for the British Industrial Biological Research Association, 42(2), pp. 237-243.

[13] Gadalla, Y. M. et al. (2012) 'Prevalence of smoking among school adolescents in Khartoum State', Sudanese journal of paediatrics, 12(2), pp. 44-48.

[14] Girija, S. A., Jayaseelan, V. P. and Arumugam, P. (2018) 'Prevalence of VIM- and GIM-producing Acinetobacter baumannii from patients with severe urinary tract infection', Acta microbiologica et immunologica Hungarica, 65(4), pp. 539-550.

[15] Govindaraju, L., Neelakantan, P. and Gutmann, J. L. (2017) 'Effect of root canal irrigating solutions on the compressive strength of tricalcium silicate cements', Clinical oral investigations, 21(2), pp. 567-571.

[16] Hawkins, J. D., Catalano, R. F. and Miller, J. Y. (1992) 'Risk and protective factors for alcohol and other drug problems in adolescence and early adulthood: implications for substance abuse prevention', Psychological bulletin, 112(1), pp. 64-105.

[17] Henschke， C. I., Yip, R. and 
Miettinen, O. S. (2006)

'International Early Lung Cancer.

Action Program Investigators...

Women's susceptibility to tobacco carcinogens and survival after diagnosis of lung cancer', JAMA: the journal of the American Medical Association, 296, pp. 180-184.

[18] Heo, J. et al. (2014) 'Household and school-level influences on smoking behavior among Korean adolescents: a multilevel analysis', PloS one, 9(6), p. e98683.

[19] Howard, G. et al. (1998) 'Cigarette smoking and progression of atherosclerosis: The Atherosclerosis Risk in Communities (ARIC) Study', JAMA: the journal of the American Medical Association, 279(2), pp. 119-124.

[20] Leatherdale, S. T. and Manske, S. (2005) 'The relationship between student smoking in the school environment and smoking onset in elementary school students', Cancer epidemiology, biomarkers \& prevention: a publication of the American Association for Cancer Research, cosponsored by the American Society of Preventive Oncology, 14(7), pp. 1762-1765.
[21] Lim, K. H. et al. (2017) 'Smoking among school-going adolescents in selected secondary schools in Peninsular Malaysia- findings from the Malaysian Adolescent Health Risk Behaviour (MyaHRB) study', Tobacco induced diseases, 15, p. 9.

[22] Linetzky, B. et al. (2012) 'Socioeconomic status and tobacco consumption among adolescents: a multilevel analysis of Argentina's Global Youth Tobacco Survey', Nicotine \& tobacco research: official journal of the Society for Research on Nicotine and Tobacco, 14(9), pp. 1092-1099.

[23] Manohar, J. and Abilasha, R. (2019) 'A Study on the Knowledge of Causes and Prevalance of Pigmentation of Gingiva among Dental Students', Indian Journal of Public Health Research \& Development, p. $95 . \quad$ doi: 10.5958/0976-5506.2019.01859.x.

[24] Mathew, M. G. et al. (2020) 'Evaluation of adhesion of Streptococcus mutans, plaque accumulation on zirconia and stainless steel crowns, and surrounding gingival inflammation in primary molars: Randomized 
controlled trial', Clinical oral investigations, pp. 1-6.

[25] Meijer, B. et al. (1996) 'Cigarette smoking habits among schoolchildren', Chest, 110(4), pp. 921-926.

[26] Muthukrishnan,

A. and Warnakulasuriya, S. (2018) 'Oral health consequences of smokeless tobacco use', The Indian journal of medical research, 148(1), pp. 3540.

[27] Nakachi, K. et al. (1993) 'Polymorphisms of the CYP1A1 and glutathione S-transferase genes associated with susceptibility to lung cancer in relation to cigarette dose in a Japanese population', Cancer research, 53(13), pp. 2994 2999.

[28] National Center for Chronic Disease Prevention and Health Promotion (US) Office on Smoking and Health (2012) Preventing Tobacco Use Among Youth and Young Adults: A Report of the Surgeon General. Atlanta (GA): Centers for Disease Control and Prevention (US).

[29] Okada, T. et al. (1994) 'Assciation between a cytochrome P450 CYPIA1 genotype and incidence of lung cancer', Pharmacogenetics, pp. 333-340. doi: 10.1097/00008571199412000-00006.

[30] Organization, W. H. and Others (2011) WHO report on the global tobacco epidemic, 2011: warning about the dangers of tobacco. Geneva: World Health Organization.

[31] Pc, J., Marimuthu, T. and Devadoss, P. (2018) 'Prevalence and measurement of anterior loop of the mandibular canal using CBCT: A cross sectional study', Clinical implant dentistry and related research. Available at: https://europepmc.org/article/med/2 9624863.

[32] Priyadharsini, J. V. et al. (2018) 'In silico analysis of virulence genes in an emerging dental pathogen A. baumannii and related species', Archives of Oral Biology, pp. 9398. doi: 10.1016/j.archoralbio.2018.07.001.

[33] Priyanka, S. et al. (2017) 'Detection of cytomegalovirus, Epstein-Barr virus, and Torque Teno virus in subgingival and atheromatous plaques of cardiac patients with chronic periodontitis', Journal of 
Indian Society of Periodontology, 21(6), pp. 456-460.

- P. W. et al. (2004) 'School effects on pupils' health behaviours: evidence in support of the health promoting school', Research Papers in Education, pp. 261-291. doi: 10.1080/02671522.2004.10058645.

[34] Ramadurai, N. et al. (2019) 'Effectiveness of 2\% Articaine as an anesthetic agent in children: randomized controlled trial', Clinical oral investigations, 23(9), pp. 3543-3550.

[35] Ramesh, A. et al. (2018) 'Comparative estimation of sulfiredoxin levels between chronic periodontitis and healthy patients A case-control study', Journal of periodontology, 89(10), pp. 12411248.

[36] R, H. et al. (2020) 'CYP2 C9 polymorphism among patients with oral squamous cell carcinoma and its role in altering the metabolism of benzo[a]pyrene', Oral Surgery, Oral Medicine, Oral Pathology and Oral Radiology, pp. 306-312. doi: 10.1016/j.oooo.2020.06.021

[37] Saha, S. P. et al. (2007) 'Cigarette smoke and adverse health effects:
An overview of research trends and future needs', The International journal of angiology: official publication of the International College of Angiology, Inc, 16(3), pp. 77-83.

[38] Samuel, S. R. (2021) 'Can 5-yearolds sensibly self-report the impact of developmental enamel defects on their quality of life?', International journal of paediatric dentistry / the British Paedodontic Society [and] the International Association of Dentistry for Children, 31(2), pp. 285-286.

[39] Sheriff, K. A. H., Ahmed Hilal Sheriff, K. and Santhanam, A. (2018) 'Knowledge and Awareness towards Oral Biopsy among Students of Saveetha Dental College', Research Journal of Pharmacy and Technology, p. 543. doi: $10.5958 / 0974-$ 360x.2018.00101.4.

[40] Sitharthan, R. et al. (2019) 'Automated power management strategy for wind power generation system using pitch angle controller', Measurement and Control, 52(3-4), pp. 169-182.

[41] Sridharan, G. et al. (2019) 
'Evaluation of salivary

metabolomics in oral leukoplakia and oral squamous cell carcinoma', Journal of oral pathology \& medicine: official publication of the International Association of Oral Pathologists and the American Academy of Oral Pathology, 48(4), pp. 299-306.

[42] Tyas, S. L. and Pederson, L. L. (1998) 'Psychosocial factors related to adolescent smoking: a critical review of the literature', Tobacco control, 7(4), pp. 409-420.

[43] Venu, H., Dhana Raju, V. and Subramani, L. (2019) 'Combined effect of influence of nano additives, combustion chamber geometry and injection timing in a DI diesel engine fuelled with ternary (dieselbiodiesel-ethanol) blends', Energy, pp. 386-406. doi: 10.1016/j.energy.2019.02.163.

[44] Vijayashree Priyadharsini, J. (2019) 'In silico validation of the nonantibiotic drugs acetaminophen and ibuprofen as antibacterial agents against red complex pathogens', Journal of periodontology, 90(12), pp. 1441-1448.

[45] Vijayashree Priyadharsini, J.,
Smiline Girija, A. S. and Paramasivam, A. (2018) 'In silico analysis of virulence genes in an emerging dental pathogen A. baumannii and related species', Archives of oral biology, 94, pp. 9398.

[46] Wang, Y. et al. (2019) 'Synthesis of Zinc oxide nanoparticles from Marsdenia tenacissima inhibits the cell proliferation and induces apoptosis in laryngeal cancer cells (Hep-2)', Journal of photochemistry and photobiology. B, Biology, 201, p. 111624 .

[47] Wu, F. et al. (2019) 'Biologically synthesized green gold nanoparticles from Siberian ginseng induce growth-inhibitory effect on melanoma cells (B16)', Artificial cells, nanomedicine, and biotechnology , 47(1), pp. 32973305. 